\title{
TREN JARAK KELAHIRAN PENDEK PADA PENGGUNA KONTRASEPSI DI INDONESIA 2002 - 2017 (ANALISIS DATA SURVEI DEMOGRAFI DAN KESEHATAN)
}

\author{
Short Birth Interval Trend Among Contraceptive Users in Indonesia 2002 - 2017 \\ (Demographic and Health Survey Data Analysis)
}

\author{
Adelina Fitri ${ }^{1}$ \\ ${ }^{1}$ Program Studi Ilmu Kesehatan Masyarakat, Universitas Jambi
}

\begin{abstract}
Abstrak
Jarak kelahiran dapat diartikan sebagai jarak antara terjadinya suatu penghentian kehamilan (lahir hidup atau mati) dengan terjadinya kelahiran berikutnya. Jarak kelahiran yang pendek didefinisikan jika kelahiran terjadi kurang dari 24 bulan setelah kelahiran sebelumnya. Ibu yang melahirkan kembali dalam waktu singkat tentunya memiliki tingkat kesuburan yang sangat baik. Salah satu cara yang dapat dilakukan untuk mencegah terjadinya jarak kelahiran pendek adalah dengan menggunakan kontrasepsi. Tujuan penelitian ini untuk melihat tren jarak kelahiran pendek $<24$ bulan pada pengguna kontrasepsi di Indonesia. Penelitian menggunakan data Survei Demografi Kesehatan Indonesia 2002 - 2017 dengan desain studi cross sectional. Jumlah ibu yang menjadi sampel setelah diterapkan kriteria inklusi dan eksklusi sebanyak 9644 (2002), 10470 (2007), 10162 (2012) dan 10854 (2017). Untuk tren persentase jarak kelahiran pendek $(<24$ bulan) pada pengguna kontrasepsi di Indonesia mengalami peningkatan 2002 - 2017 yaitu 61,07\% (2012), 62,63\% (2007), 65,27\% (2012) dan 68,04\% (2017). Penggunaan kontrasepsi belum cukup efisien untuk mencegah terjadinya jarak kelahiran pendek $(<24$ bulan $)$ di Indonesia.
\end{abstract}

Kata Kunci : Jarak Kelahiran, Kontrasepsi, Kehamilan

\begin{abstract}
Birth interval can be interpreted as the distance between the occurrence of a termination of pregnancy (live or stillbirth) with the occurrence of subsequent births. Short birth interval is defined if the birth occurs less than 24 months after the previous birth. Maternal who give birth in a short time certainly have a very good fertility rate. One of many way that can be done to prevent short birth intervals is to use contraception. The purpose of this study was to look at the trend of short birth intervals <24 months on contraceptive users in Indonesia. The study used data from the 2002-2017 Indonesian Demographic and Health Survey with cross sectional study design. The number of maternal who were sampled after applying the inclusion and exclusion criteria are 9644 (2002), 10470 (2007), 10162 (2012) dan 10854 (2017). For the percentage of short birth interval ( $<24$ months) on contraceptive users in Indonesia increased from 2002 - 2017 i.e. 61,07\% (2012), 62,63\% (2007), 65,27\% (2012) dan 68,04\% (2017). The use of contraception is not efficient enough to prevent short birth interval ( $<24$ months) in Indonesia.

Keywords : Birth Interval, Contraceptive, Pregnancy
\end{abstract}

Korespondensi : Adelina Fitri

Email : adelinafitri@unja.ac.id

\section{PENDAHULUAN}

Berdasarkan data dari United Nation, Indonesia merupakan negara yang memiliki jumlah penduduk terbanyak nomor empat di dunia setelah China, India dan Amerika

Serikat, dengan estimasi populasi penduduk 270 juta pada tahun 2019. Selanjutnya, angka kelahiran Indonesia 
berada pada peringkat ke lima di Asia Tenggara dimana Total Fertility Rate (TFR) $=2,3$ (1). TFR merupakan indikator demografi yang paling umum digunakan. TFR juga memiliki kaitan yang erat dengan prevalens kontrasepsi dan indikator lainnya pada kesehatan reproduksi seperti Angka Kematian Ibu (AKI) (2).

Jarak kelahiran merupakan jarak antara terjadinya suatu kelahiran (lahir hidup atau mati) dengan kelahiran selanjutnya. Jarak kelahiran dapat memperlihatkan perilaku fertilitas dimana berperan penting pada perubahan penduduk. Ibu yang melahirkan kembali dalam waktu singkat pastinya memiliki tingkat kesuburan yang sangat baik (3). Jarak kelahiran pendek didefinisikan jika kelahiran terjadi kurang dari 24 bulan setelah kelahiran sebelumnya (4). Tren jarak kelahiran pendek di Indonesia dari tahun 2002 - 2017 cenderung mengalami penurunan yaitu $12,7 \%$ (2002), 12,8\% (12,8\%), 10,5\% (10,5\%) dan 9\% (2017). Jika dilihat penurunan proporsi jarak kelahiran pendek di Indonesia selama 15 tahun hanya sebesar 3,7\%. Kontrasepsi merupakan salah satu cara yang dapat dilakukan untuk mencegah terjadinya kehamilan serta mengatur jarak kelahiran.

Kontrasepsi atau Keluarga Berencana di Indonesia merupakan program yang sudah dimulai sejak tahun 1957. Program KB memiliki tujuan untuk menekan jumlah penduduk serta meningkatkan kesehatan ibu dan anak (5). Sebelum adanya KB di Indonesia TFR mencapai 5,6 yang mempunyai arti bahwa wanita di Indonesia mampu melahirkan 5-6 anak sepanjang usia reproduksi. Setelah program KB dilaksanakan, terjadi perubahan persepsi di masyarakat mengenai jumlah ideal anak yang dimiliki yang menyebabkan penurunan angka kelahiran (6).
Berdasarkan data Survei Demografi Kesehatan Indonesia (SDKI) 2017 TFR Indonesia sebesar 2,4 (7). Dari data di atas dapat diambil kesimpulan bahwa Indonesia mampu mengurangi lebih dari setengah angka fertilitas pada tahun 2017. Berdasarkan data SDKI 2012 tren prevalensi penggunaan kontrasepsi (CPR) di Indonesia cenderung meningkat dari tahun 1991 - 2012 yaitu 49,7\% - 61,9\%, sementara tren angka fertilitas (TFR) cenderung menurun yaitu dari $3-2,6$.

Berdasarkan latar belakang tersebut penelitian ini ingin melihat bagaimana tren jarak kelahiran pendek pada pengguna kontrasepsi di Indonesia.

\section{METODE}

Penelitian ini menggunakan data sekunder SDKI tahun 2002 - 2017 dengan rancangan penelitian cross-sectional. Analisis data yang dilakukan jika menggunakan data SDKI juga harus mempertimbangkan bobot (weight). Analisis dengan pembobotan dapat dilakukan dengan complex sample. Jika menggunakan analisis biasa maka hasil tidak akan tepat, karena probabilitas sampel untuk terpilih tidak sama. Analisis dilakukan hanya sebatas pada analisis univariat yaitu memperlihatkan distribusi frekuensi dan karakteristik dari variabel yang diteliti yaitu jarak kelahiran, pengguna kontrasepsi, usia ibu saat melahirkan, paritas, tempat tinggal, pendidikan ibu, indeks kekayaan dan asuransi kesehatan. Akan tetapi data mengenai asuransi kesehatan hanya terdapat pada SDKI tahun 2012 dan 2017.

Populasi merupakan seluruh wanita di Indonesia yang menjadi sampel SDKI 2002 - 2017. Sampel pada penelitian ini menerapkan kriterai inklusi yaitu anak terakhir yang dilahirkan oleh ibu dalam 
rentang waktu lima tahun sebelum survei dilaksanakan, sedangkan kriteria eksklusi yaitu anak pertama, kelahiran kembar dan data missing. Kemudian didapatkan ibu yang menjadi sampel pada penelitian sebanyak 9644 (Tahun 2002), 10470 (Tahun 2007), 10162 (Tahun 2012) dan 10854 (Tahun 2017). Penelitian dengan menggunakan data DHS dimanfaatkan sepenuhnya untuk perkembangan ilmu pengetahuan di bidang kesehatan ibu dan anak. Identitas responden yang menjadi sampel dalam penelitian ini dirahasikan untuk umum.

\section{HASIL PENELITIAN}

Gambar 1. memperlihatkan persentase jarak kelahiran pendek $(<24$ bulan) pada pengguna kontrasepsi di Indonesia dari tahun 2002 - 2017. Dapat dilihat persentase jarak kelahiran pendek pada pengguna kontrasepsi mengalami peningkatan dalam rentang waktu 2002 hingga 2017 yaitu 61,07\% (Tahun 2012), $62,63 \%$ (Tahun 2007), 65,27\% (Tahun 2012) dan 68,04\% (Tahun 2017).

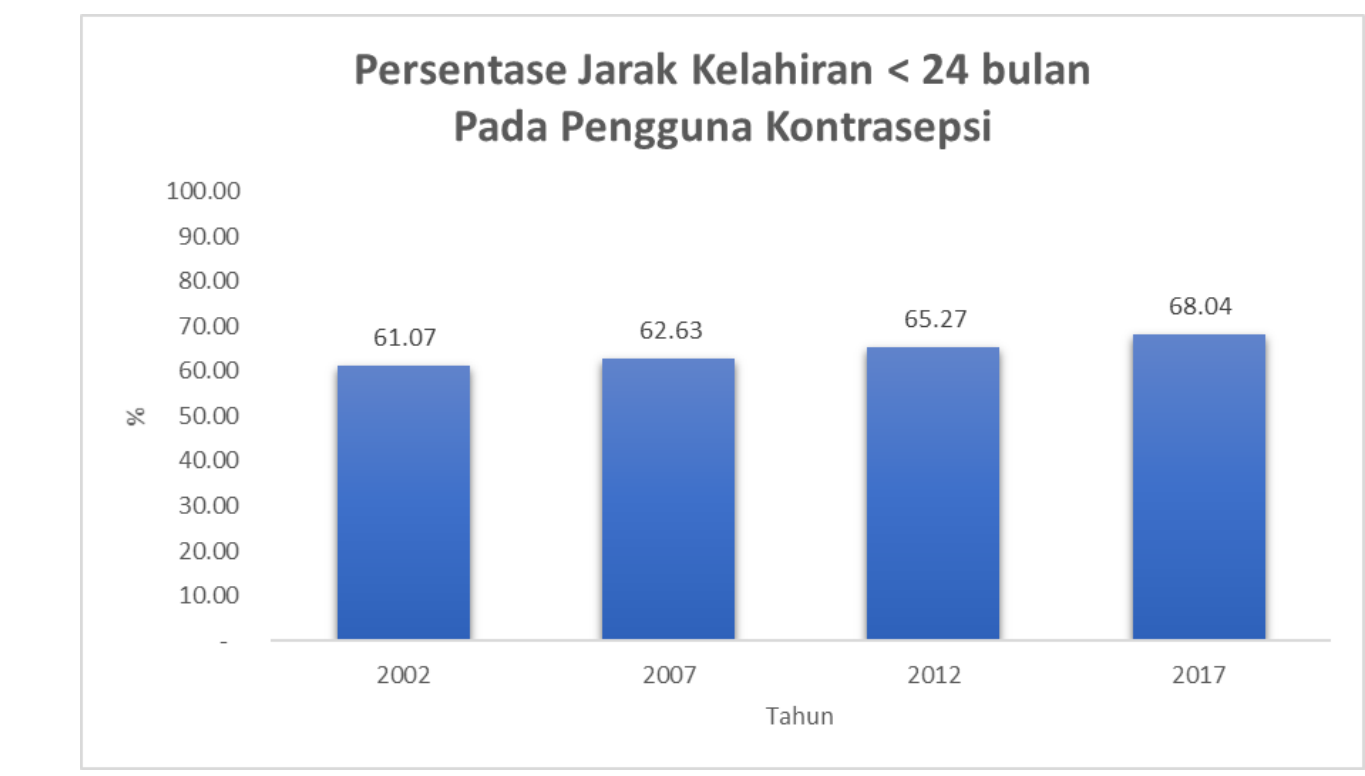

\section{Gambar 1. Bar Diagram Persentase Jarak Kelahiran < 24 bulan Pada Pengguna Kntrasepsi di Indonesia}

Berdasarkan hasil stratifikasi pada variabel usia melahirkan, paritas, tempat tinggal, pendidikan ibu, indeks kekayaan, proporsi jarak kelahiran pendek pada pengguna kontrasepsi lebih besar pada usia 20-35 tahun yaitu $64,51 \%$ (2002), 63,59\% (2007), 65,84 (2012) dan > 35 tahun pada tahun 2017. Proporsi jarak kelahiran $<24$ bulan pada pengguna kontrasepsi lebih besar ditemukan pada ibu yang melahirkan anak 2-3 yaitu $67,16 \%$ (2002), $65,18 \%$
(2007), sedangkan pada tahun 2012 dan 2017 proporsi jarak kelahiran pendek pada pengguna kontrasepsi lebih banyak ditemukan pada ibu dengan paritas 4-6 yaitu 69,61\% (2012) dan 69,56\% (2017). Berdasarkan tempat tinggal, perkotaan masih mendominasi jarak kelahiran pendek pada pengguna kontrasepsi 64,77\% (2002), $71,73 \%$ (2007), 72,38\% (2012) dan 72,34\% (2017). 
Tabel 1. Stratifikasi Jarak Kelahiran Pada Pengguna Kontrasepsi di Indonesia Tahun 2002 - 2017

\begin{tabular}{|c|c|c|c|c|c|c|c|c|c|c|c|c|c|}
\hline \multirow{3}{*}{ Variabel } & \multirow{3}{*}{$\begin{array}{c}\text { Jarak } \\
\text { Kelahiran }\end{array}$} & \multicolumn{3}{|c|}{2002} & \multicolumn{3}{|c|}{2007} & \multicolumn{3}{|c|}{2012} & \multicolumn{3}{|c|}{2017} \\
\hline & & \multicolumn{2}{|c|}{ Penggunaan Kontrasepsi } & \multirow[t]{2}{*}{ Total } & \multicolumn{2}{|c|}{ Penggunaan Kontrasepsi } & \multirow[t]{2}{*}{ Total } & \multicolumn{2}{|c|}{ Penggunaan Kontrasepsi } & \multirow[t]{2}{*}{ Total } & \multicolumn{2}{|c|}{ Penggunaan Kontrasepsi } & \multirow[t]{2}{*}{ Total } \\
\hline & & Iya $(\%)$ & Tidak (\%) & & Iya $(\%)$ & Tidak (\%) & & Iya $(\%)$ & Tidak (\%) & & Iya $(\%)$ & Tidak (\%) & \\
\hline \multicolumn{14}{|l|}{$\begin{array}{l}\text { Usia Ibu Saat } \\
\text { Melahirkan }\end{array}$} \\
\hline \multirow[t]{2}{*}{$<20$ tahun } & $<24$ bulan & $40(57.65)$ & $29(42.35)$ & $69(100)$ & $43(57,20)$ & $32(42,80)$ & $75(100)$ & $19(57,47)$ & $14(42,53)$ & $34(100)$ & $19(57,39)$ & $14(42,61)$ & $33(100)$ \\
\hline & $\geq 24$ bulan & $87(64.10)$ & $49(35,90)$ & $136(100)$ & $46(65,33)$ & $24(34,67)$ & $70(100)$ & $22(62,51)$ & $13(37,49)$ & $35(100)$ & $16(51,29)$ & $15(48,71)$ & $31(100)$ \\
\hline \multirow[t]{2}{*}{20 - 35 tahun } & $<24$ bulan & $655(64,51)$ & $361(35,49)$ & $1016(100)$ & $722(63,59)$ & $413(36,41)$ & $1135(100)$ & $587(65,84)$ & $304(34,16)$ & $891(100)$ & $534(67,22)$ & $261(32,78)$ & $795(100)$ \\
\hline & $\geq 24$ bulan & $4749(70,20)$ & $2016(29,80)$ & $6764(100)$ & $5392(74,45)$ & $1851(25,55)$ & $7243(100)$ & $5463(77,78)$ & $1561(22,22)$ & $7024(100)$ & $5888(78,48)$ & $1614(21,52)$ & $7502(100)$ \\
\hline \multirow[t]{2}{*}{$>35$ tahun } & $<24$ bulan & $56(38,69)$ & $90(61,31)$ & $146(100)$ & $76(57,45)$ & $57(42,55)$ & $133(100)$ & $91(63,62)$ & $52(36,38)$ & $143(100)$ & $103(75,28)$ & $34(24,72)$ & $137(100)$ \\
\hline & $\geq 24$ bulan & $891(58,85)$ & $623(41,15)$ & $1513(100)$ & $1112(61,31)$ & $702(38,69)$ & $1813(100)$ & $1431(70,28)$ & $605(29,72)$ & $2036(100)$ & $1791(76,05)$ & $564(23,95)$ & $2355(100)$ \\
\hline \multicolumn{14}{|l|}{ Paritas } \\
\hline \multirow[t]{2}{*}{$2-3$} & $<24$ bulan & $554(67,16)$ & $271(32,84)$ & $825(100)$ & $612(65,18)$ & $327(34,82)$ & $939(100)$ & $489(67,75)$ & $233(32,25)$ & $722(100)$ & $461(67,76)$ & $219(32,24)$ & $680(100)$ \\
\hline & $\geq 24$ bulan & $4237(73,29)$ & $1544(26,71)$ & $5781(100)$ & $4916(75,94)$ & $1557(24,06)$ & $6473(100)$ & $5512(78,44)$ & $1515(21,56)$ & $7027(100)$ & $6302(78,86)$ & $1689(21,14)$ & $7990(100)$ \\
\hline \multirow[t]{2}{*}{$4-6$} & $<24$ bulan & $144(54,88)$ & $118(45,12)$ & $262(100)$ & $199(59,68)$ & $134(40,32)$ & $333(100)$ & $186(69,61)$ & $81(30,39)$ & $267(100)$ & $151(69,56)$ & $66(30,44)$ & $217(100)$ \\
\hline & $\geq 24$ bulan & $1257(59,13)$ & $869(40,87)$ & $2126(100)$ & $1475(65,24)$ & $786(34,76)$ & $2261(100)$ & $1263(71,00)$ & $516(29,00)$ & $1779(100)$ & $1299(75,37)$ & $425(24,63)$ & $1724(100)$ \\
\hline \multirow[t]{2}{*}{$>6$} & $<24$ bulan & $54(37,49)$ & $90(62,51)$ & $144(100)$ & $30(42,68)$ & $41(57,32)$ & $71(100)$ & $22(27,93)$ & $57(72,07)$ & $79(100)$ & $45(65,91)$ & $23(34,09)$ & $68(100)$ \\
\hline & $\geq 24$ bulan & $232(45,84)$ & $274(54,16)$ & $506(100)$ & $160(40,64)$ & $233(59,36)$ & $393(100)$ & $141(48,83)$ & $148(51,17)$ & $289(100)$ & $94(54,14)$ & $80(45,86)$ & $174(100)$ \\
\hline \multicolumn{14}{|l|}{ Tempat Tinggal } \\
\hline \multirow[t]{2}{*}{ Perkotaan } & $<24$ bulan & $395(64,77)$ & $215(35,23)$ & $610(100)$ & $383(71,73)$ & $151(28,27)$ & $534(100)$ & $354(72,38)$ & $135(27,62)$ & $489(100)$ & $337(72,34)$ & $129(27,66)$ & $466(100)$ \\
\hline & $\geq 24$ bulan & $2670(71,37)$ & $1071(28,63)$ & 3741 (100) & $2766(76,15)$ & $866(23,85)$ & $3632(100)$ & $3554(79,15)$ & $936(20,85)$ & $4490(100)$ & $3760(79,03)$ & $998(20,97)$ & $4758(100)$ \\
\hline \multirow[t]{2}{*}{ Perdesaan } & $<24$ bulan & $357(57,43)$ & $264(42,57)$ & $621(100)$ & $458(56,62)$ & $351(43,38)$ & $809(100)$ & $343(59,27)$ & $236(40,73)$ & $579(100)$ & $320(64,02)$ & $180(35,98)$ & $500(100)$ \\
\hline & $\geq 24$ bulan & $3056(65,41)$ & $1616(34,59)$ & $4672(100)$ & $3785(68,87)$ & $1710(31,13)$ & $5495(100)$ & $3363(73,02)$ & $1244(26,98)$ & $4605(100)$ & $3935(76,70)$ & $1196(23,30)$ & $5131(100)$ \\
\hline \multicolumn{14}{|l|}{ Pendidikan Ibu } \\
\hline \multirow[t]{2}{*}{ Tidak Sekolah } & $<24$ bulan & $31(35,31)$ & $57(64,69)$ & $88(100)$ & $25(31,57)$ & $53(68,43)$ & $78(100)$ & $12(20,48)$ & $49(79,52)$ & $61(100)$ & $15(43,27)$ & $20(56,73)$ & $35(100)$ \\
\hline & $\geq 24$ bulan & $251(48,64)$ & $266(41,36)$ & $517(100)$ & $220(52,85)$ & $196(47,15)$ & $416(100)$ & $102(45,32)$ & $124(54,68)$ & $226(100)$ & $67(48,33)$ & $71(51,67)$ & $138(100)$ \\
\hline Sekolah Dasar & $<24$ bulan & $310(56,52)$ & $238(43,48)$ & $548(100)$ & $302(59,37)$ & $207(40,63)$ & $509(100)$ & $204(63,63)$ & $117(36,37)$ & $321(100)$ & $144(60,81)$ & $93(39,19)$ & $237(100)$ \\
\hline & $\geq 24$ bulan & $3085(66,21)$ & $1574(33,79)$ & 4659 (100) & $2949(68,78)$ & $1338(31,22)$ & 4287 (100) & $2669(75,45)$ & $869(24,55)$ & $3538(100)$ & $2454(78,54)$ & $671(21,46)$ & 3125 (100) \\
\hline Sekolah Menengah & $<24$ bulan & $334(67,49)$ & $161(32,51)$ & $495(100)$ & $410(65,46)$ & $216(34,54)$ & $626(100)$ & $376(71,65)$ & $149(28,35)$ & $525(100)$ & $364(72,51)$ & $138(27,49)$ & $502(100)$ \\
\hline & $\geq 24$ bulan & $2085(73,18)$ & $764(26,82)$ & 2849 (100) & $2959(75,85)$ & $942(24,15)$ & $3901(100)$ & $3463(78,23)$ & $964(21,77)$ & $4427(100)$ & $4210(78,24)$ & $1171(21,76)$ & $5381(100)$ \\
\hline Pendidikan Tinggi & $<24$ bulan & $76(77,21)$ & $22(22,79)$ & $98(100)$ & $105(80,22)$ & $26(19,78)$ & $131(100)$ & $104(64,74)$ & $57(35,26)$ & $161(100)$ & $134(69,73)$ & $58(30,27)$ & $192(100)$ \\
\hline & $\geq 24$ bulan & $305(78,46)$ & $84(21,54)$ & $389(100)$ & $422(80,96)$ & $99(19,04)$ & $521(100)$ & $681(75,33)$ & $223(24,67)$ & $904(100)$ & $964(77,47)$ & $280(22,53)$ & $1244(100)$ \\
\hline
\end{tabular}




\begin{tabular}{|c|c|c|c|c|c|c|c|c|c|c|c|c|c|}
\hline \multicolumn{14}{|c|}{ Indeks Kekayaan } \\
\hline \multirow[t]{2}{*}{ Sangat Miskin } & $<24$ bulan & $186(48,39)$ & $199(51,61)$ & $385(100)$ & $217(51,03)$ & $208(48,97)$ & $425(100)$ & $181(49,35)$ & $186(50,65)$ & $367(100)$ & $187(58,97)$ & $130(41,03)$ & $317(100)$ \\
\hline & $\geq 24$ bulan & $1115(53,60)$ & $965(46,40)$ & $2080(100)$ & $1281(58,00)$ & $928(42,00)$ & $2209(100)$ & $169(65,03)$ & $736(34,97)$ & $2105(100)$ & $1450(70,14)$ & $618(29,86)$ & $2068(100)$ \\
\hline \multirow[t]{2}{*}{ Miskin } & $<24$ bulan & $138(65,04)$ & $74(34,96)$ & $212(100)$ & $165(63,21)$ & $96(36,79)$ & $261(100)$ & $139(72,96)$ & $52(27,04)$ & $191(100)$ & $128(77,74)$ & $37(22,26)$ & $165(100)$ \\
\hline & $\geq 24$ bulan & $1155(67,20)$ & $564(32,80)$ & $1719(100)$ & $1287(70,96)$ & $527(29,04)$ & $1814(100)$ & $1327(78,58)$ & $362(21,42)$ & $1689(100)$ & $1570(78,91)$ & $420(21,09)$ & $1990(100)$ \\
\hline \multirow[t]{2}{*}{ Menengah } & $<24$ bulan & $133(60,23)$ & $88(39,77)$ & $221(100)$ & $166(69,81)$ & $72(30,19)$ & $238(100)$ & $131(77,72)$ & $38(22,28)$ & $169(100)$ & $103(72,41)$ & $39(27,59)$ & $142(100)$ \\
\hline & $\geq 24$ bulan & $1257(74,43)$ & $432(25,57)$ & $1689(100)$ & $1353(75,04)$ & $450(24,96)$ & $1803(100)$ & $1405(80,17)$ & $347(19,83)$ & $1752(100)$ & $1592(81,69)$ & $357(18,31)$ & $1949(100)$ \\
\hline \multirow[t]{2}{*}{ Kaya } & $<24$ bulan & $140(66,94)$ & $69(33,06)$ & $209(100)$ & $126(68,69)$ & $58(31,31)$ & $184(100)$ & $110(72,82)$ & $41(27,18)$ & $151(100)$ & $117(69,44)$ & $52(30,56)$ & $169(100)$ \\
\hline & $\geq 24$ bulan & $1148(72,90)$ & $427(27,10)$ & $1575(100)$ & $1343(79,60)$ & $344(20,40)$ & $1687(100)$ & $1458(81,12)$ & $339(18,88)$ & $1797(100)$ & $1613(80,99)$ & $379(19,01)$ & $1992(100)$ \\
\hline \multirow[t]{2}{*}{ Sangat Kaya } & $<24$ bulan & $153(75,87)$ & $49(24,13)$ & $202(100)$ & $166(70,96)$ & $68(29,04)$ & $234(100)$ & $136(71,21)$ & $55(28,79)$ & $191(100)$ & $122(70,44)$ & $51(29,56)$ & $173(100)$ \\
\hline & $\geq 24$ bulan & $1050(77,80)$ & $300(22,20)$ & $1350(100)$ & $1286(79,69)$ & $328(20,31)$ & $1614(100)$ & $1357(77,50)$ & $394(22,50)$ & $1751(100)$ & $1469(77,74)$ & $421(22,26)$ & $1889(100)$ \\
\hline \multicolumn{14}{|c|}{ Asuransi Kesehatan } \\
\hline \multirow[t]{2}{*}{ Iya } & $<24$ bulan & & & & & & & $249(67,00)$ & $124(33,00)$ & $373(100)$ & $384(68,28)$ & $178(31,72)$ & $562(100)$ \\
\hline & $\geq 24$ bulan & N/A & N/A & N/A & N/A & N/A & N/A & $2745(77,70)$ & $788(22,30)$ & $3533(100)$ & $4635(78,36)$ & $1280(21,64)$ & $5915(100)$ \\
\hline \multirow[t]{2}{*}{ Tidak } & $<24$ bulan & N/A & N/A & N/A & N/A & N/A & N/A & $448(64,50)$ & $247(35,50)$ & $695(100)$ & $273(67,70)$ & $130(32,30)$ & $403(100)$ \\
\hline & $\geq 24$ bulan & $\mathrm{N} / \mathrm{A}$ & $\mathrm{N} / \mathrm{A}$ & N/A & N/A & $\mathrm{N} / \mathrm{A}$ & N/A & $4171(75,00)$ & $1391(25,00)$ & $5562(100)$ & $3061(77,01)$ & $913(22,99)$ & $3974(100)$ \\
\hline
\end{tabular}

Ibu dengan jarak kelahiran pendek dan menggunakan kontrasepsi mayoritas berasal dari pendidikan tinggi yaitu 77,21\% (2002), 80,22\% (2007), sedangkan untuk tahun 2012 dan 2017 berasal dari ibu yang menamatkan sekolah menengah 71,65\% dan $72,51 \%$. Hasil strata pada variabel asuransi kesehatan hanya tersedia untuk tahun 2012 dan 2017 dimana proporsi ibu yang melahirkan kembali dengan jarak < 24 bulan dan menggunakan kontrasepsi lebih besar pada ibu yang memiliki asuransi kesehatan yaitu 67,00\% (2012) dan 68,28\% (2017). Dari hasil analisis bivariat didapatkan kategori usia ibu saat melahirkan protektif terhadap asosiasi penggunaan kontrasepsi pada jarak kelahiran pendek pada tahun 2002 - 2012, sedangkan untuk tahun 2017, ibu yang melahirkan pada usia $<20$ tahun dan menggunakan kontrasepsi lebih berisiko untuk melahirkan kembali dalam rentang waktu $<24$ bulan (RR 1,13 95\% CI 0,691,84). Ibu yang melahirkan anak $>6$ dan menggunakan kontrasepsi juga lebih berisiko untuk memiliki jarak kelahiran pendek pada tahun 2007 (RR 1,07 95\% CI 0,69 - 1,65) dan 2012 (RR 1,43 95\% CI 0,93 $-2,21)$. Jika dilihat dari tempat tinggal, ibu yang tinggal di daerah perkotaan dan menggunakan kontrasepsi lebih protektif terhadap jarak kelahiran pendek dibandingkan dengan ibu yang tinggal di daerah perdesaan. 
Tabel 2. Asosiasi Jarak Kelahiran Pada Pengguna Kontrasepsi di Indonesia Tahun 2002 - 2017 Distratifikasi Dengan Beberapa Variabel

\begin{tabular}{|c|c|c|c|c|c|c|c|c|c|c|c|c|c|}
\hline \multirow[t]{2}{*}{ Variabel } & \multirow{2}{*}{$\begin{array}{l}\text { Penggunaan } \\
\text { Kontrasepsi }\end{array}$} & \multicolumn{3}{|c|}{2002} & \multicolumn{3}{|c|}{2007} & \multicolumn{3}{|c|}{2012} & \multicolumn{3}{|c|}{2017} \\
\hline & & RR & $95 \% \mathrm{CI}$ & p-value & RR & $95 \% \mathrm{CI}$ & p-value & $\mathbf{R R}$ & $95 \%$ CI & p-value & RR & $95 \% \mathrm{CI}$ & p-value \\
\hline \multicolumn{14}{|l|}{$\begin{array}{l}\text { Usia Ibu Saat } \\
\text { Melahirkan }\end{array}$} \\
\hline \multirow[t]{2}{*}{$<20$ tahun } & Iya & 0,84 & $0,57-1,23$ & 0,365 & 0,85 & $0,62-1,16$ & 0,309 & 0,90 & $0,56-1,45$ & 0,667 & 1,13 & $0,69-1,84$ & 0,628 \\
\hline & Tidak & Ref & & & Ref & & & Ref & & & Ref & & \\
\hline \multirow[t]{2}{*}{20 - 35 tahun } & Iya & 0,79 & $0,71-0,90$ & 0,0005 & 0,65 & $0,58-0,72$ & 0,0005 & 0,59 & $0,52-0,68$ & 0,0005 & 0,59 & $0,52-0,69$ & 0,0005 \\
\hline & Tidak & Ref & & & Ref & & & Ref & & & Ref & & \\
\hline \multirow[t]{2}{*}{$>35$ tahun } & Iya & 0,47 & $0,35-0,65$ & 0,0005 & 0,86 & $0,62-1,19$ & 0,378 & 0,76 & $0,54-1,05$ & 0,094 & 0,96 & $0,66-1,40$ & 0,838 \\
\hline & Tidak & Ref & & & Ref & & & Ref & & & Ref & & \\
\hline \multicolumn{14}{|l|}{ Paritas } \\
\hline \multirow[t]{2}{*}{$2-3$} & Iya & 0,77 & $0,68-0,89$ & 0,0005 & 0,64 & $0,56-0,72$ & 0,0005 & 0,61 & $0,53-0,71$ & 0,0005 & 0,59 & $0,51-0,69$ & 0,0005 \\
\hline & Tidak & Ref & & & Ref & & & Ref & & & Ref & & \\
\hline \multirow[t]{2}{*}{$4-6$} & Iya & 0,86 & $0,68-1,08$ & 0,187 & 0,81 & $0,66-0,99$ & 0,048 & 0,94 & $0,74-1,20$ & 0,639 & 0,77 & $0,58-1,01$ & 0,062 \\
\hline & Tidak & Ref & & & Ref & & & Ref & & & Ref & & \\
\hline \multirow[t]{2}{*}{$>6$} & Iya & 0,76 & $0,57-1,03$ & 0,078 & 1,07 & $0,69-1,65$ & 0,747 & 0,49 & $0,31-0,76$ & 0,002 & 1,43 & $0,93-2,21$ & 0,103 \\
\hline & Tidak & Ref & & & Ref & & & Ref & & & Ref & & \\
\hline \multicolumn{14}{|l|}{ Tempat Tinggal } \\
\hline \multirow[t]{2}{*}{ Perkotaan } & Iya & 0,77 & $0,66-0,89$ & 0,0005 & 0,82 & $0,69-0,98$ & 0,026 & 0,72 & $0,59-0,87$ & 0,001 & 0,72 & $0,59-0,87$ & 0,001 \\
\hline & Tidak & Ref & & & Ref & & & Ref & & & Ref & & \\
\hline \multirow[t]{2}{*}{ Perdesaan } & Iya & 0,74 & $0,64-0,86$ & 0,0005 & 0,63 & $0,56-0,72$ & 0,0005 & 0,58 & $0,49-0,68$ & 0,0005 & 0,58 & $0,48-0,68$ & 0,0005 \\
\hline & Tidak & Ref & & & Ref & & & Ref & & & Ref & & \\
\hline \multicolumn{14}{|l|}{ Pendidikan Ibu } \\
\hline \multirow[t]{2}{*}{ Tidak Sekolah } & Iya & 0,62 & $0,42-0,93$ & 0,022 & 0,47 & $0,30-0,73$ & 0,001 & 0,39 & $0,22-0,69$ & 0,001 & 0,85 & $0,47-1,55$ & 0,595 \\
\hline & Tidak & Ref & & & Ref & & & Ref & & & Ref & & \\
\hline \multirow[t]{2}{*}{ Sekolah Dasar } & Iya & 0,69 & $0,59-0,81$ & 0,0005 & 0,69 & $0,59-0,82$ & 0,0005 & 0,59 & $0,48-0,74$ & 0,0005 & 0,46 & $0,36-0,58$ & 0,0005 \\
\hline & Tidak & Ref & & & Ref & & & Ref & & & Ref & & \\
\hline \multirow[t]{2}{*}{ Sekolah Menengah } & Iya & 0,79 & $0,67-0,94$ & 0,009 & 0,65 & $0,56-0,76$ & 0,0005 & 0,73 & $0,61-0,87$ & 0,001 & 0,76 & $0,63-0,91$ & 0,003 \\
\hline & Tidak & Ref & & & Ref & & & Ref & & & Ref & & \\
\hline \multirow[t]{2}{*}{ Pendidikan Tinggi } & Iya & 0,94 & $0,62-1,43$ & 0,788 & 0,96 & $0,65-1,41$ & 0,847 & 0,65 & $0,49-0,88$ & 0,005 & 0,71 & $0,54-0,94$ & 0,018 \\
\hline & Tidak & Ref & & & Ref & & & Ref & & & Ref & & \\
\hline
\end{tabular}




\begin{tabular}{|c|c|c|c|c|c|c|c|c|c|c|c|c|c|}
\hline \multicolumn{14}{|c|}{ Indeks Kekayaan } \\
\hline \multirow[t]{2}{*}{ Sangat Miskin } & Iya & 0,84 & $0,69-1,01$ & 0,060 & 0,79 & $0,66-0,94$ & 0,008 & 0,58 & $0,48-0,69$ & 0,0005 & 0,66 & $0,53-0,81$ & 0,0005 \\
\hline & Tidak & Ref & & & Ref & & & Ref & & & Ref & & \\
\hline \multirow[t]{2}{*}{ Miskin } & Iya & 0,92 & $0,70-1,19$ & 0,527 & 0,74 & $0,58-0,93$ & 0,010 & 0,76 & $0,56-1,03$ & 0,074 & 0,94 & $0,66-1,33$ & 0,722 \\
\hline & Tidak & Ref & & & Ref & & & Ref & & & Ref & & \\
\hline \multirow[t]{2}{*}{ Menengah } & Iya & 0,57 & $0,44-0,73$ & 0,0005 & 0,79 & $0,61-1,02$ & 0,081 & 0,87 & $0,62-1,24$ & 0,447 & 0,61 & $0,43-0,87$ & 0,006 \\
\hline & Tidak & Ref & & & Ref & & & Ref & & & Ref & & \\
\hline \multirow[t]{2}{*}{ Kaya } & Iya & 0,78 & $0,59-1,02$ & 0,069 & 0,60 & $0,45-0,80$ & 0,001 & 0,65 & $0,46-0,91$ & 0,013 & 0,57 & $0,41-0,77$ & 0,0005 \\
\hline & Tidak & Ref & & & Ref & & & Ref & & & Ref & & \\
\hline \multirow[t]{2}{*}{ Sangat Kaya } & Iya & 0,91 & $0,67-1,23$ & 0,538 & 0,67 & $0,51-0,86$ & 0,002 & 0,74 & $0,55-0,99$ & 0,050 & 0,71 & $0,52-0,96$ & 0,028 \\
\hline & Tidak & Ref & & & Ref & & & Ref & & & Ref & & \\
\hline \multicolumn{14}{|c|}{ Asuransi Kesehatan } \\
\hline \multirow[t]{2}{*}{ Iya } & Iya & N/A & N/A & N/A & N/A & N/A & N/A & 0,61 & $0,49-0,75$ & 0,0005 & 0,63 & $0,53-0,74$ & 0,0005 \\
\hline & Tidak & & & & & & & Ref & & & Ref & & \\
\hline \multirow[t]{2}{*}{ Tidak } & Iya & N/A & N/A & N/A & N/A & N/A & N/A & 0,64 & $0,56-0,74$ & 0,0005 & 0,66 & $0,54-0,79$ & 0,0005 \\
\hline & Tidak & & & & & & & Ref & & & Ref & & \\
\hline
\end{tabular}

Untuk pendidikan ibu, ibu yang tidak sekolah dan menggunakan kontrasepsi lebih protektif pada jarak kelahiran pendek pada tahun 2002 - 2012 dan pada tahun 2017 ibu yang tamat sekolah dasar dan menggunakan kontrasepsi lebih protektif pada jarak kelahiran < 24 bulan (RR 0,46 95\% CI 0,36-0,58). Ibu yang berasal dari keluarga menengah (2002), kaya (2007), sangat miskin (2012), kaya (2017) dan menggunakan kontrasepsi mencegah terjadinya jarak kelahiran pendek. Ibu yang memiliki asuransi kesehatan dan menggunakan kontrasepsi juga lebih protektif terhadap jarak kelahiran pendek pada tahun 2012 (RR 0,61 95\% CI 0,49-0,75) dan 2017 (RR 0,63 95\% CI 0,53-0,74). 


\section{PEMBAHASAN}

Pada penelitian ini tren jarak kelahiran pendek pada pengguna kontrasepsi di Indonesia dari tahun 2002 2017 terus meningkat. Kontrasepsi atau Keluarga Berencana (KB) sendiri merupakan salah satu upaya untuk mengatur jarak kelahiran. Menurut penelitian Gebrehiwot et al. (2019), ibu yang sama sekali tidak menggunakan kontrasepsi memiliki risiko lebih tinggi sebesar 2,44 kali untuk melahirkan kembali dalam waktu yang pendek ( $<33$ bulan) (AOR 2,44; 95\% CI 1,55-3,82) (8). White et al (2015) mengatakan bahwa kontrasepsi tidak begitu efektif dalam mencegah terjadinya kehamilan dikarenakan banyak ibu yang kurang tertarik dengan menggunakan metode kontransepsi karena efek yang ditimbulkan. Seperti contoh penggunaan implan yang harus dimasukan ke bawah kulit bagian lengan. Selain itu ada beberapa jenis kontrasepsi yang tidak ditanggung oleh asuransi kesehatan sehingga ibu harus mengeluarkan biaya lebih untuk menggunakan kontrasepsi (9).

Dari hasil juga didapatkan bahwa pendidikan tinggi memiliki proporsi yang lebih besar pada jarak kelahiran pendek meskipun mereka menggunakan kontrasepsi. Penelitian ini sejalan dengan penelitian Kurniawati dan Prasetyo (2016) yang mengatakan bahwa ibu dengan pendidikan tinggi memiliki risiko lebih tinggi 1,51 kali untuk mempunyai jarak kelahiran pendek dibandingkan ibu dengan pendidikan rendah (10). Penelitian lain di Ethiopia memperlihatkan jarak kelahiran pendek biasa ditemukan pada ibu dengan pendidikan yang rendah (11). Perbedaan hasil penelitian ini salah satunya dapat disebabkan oleh penerapan kriteria inklusi dan eksklusi yang berbeda pada masingmasing penelitian.
Ibu yang memiliki asuransi kesehatan merupakan faktor protektif pada ibu dengan jarak kelahiran pendek dan menggunakan kontrasepsi pada tahun 2002 - 2017. Asuransi kesehatan nasionall didirikan dengan tujuan untuk meningkatkan akses ke pelayanan kesehatan dan kesehatan ibu lainnya yang nantinya diharapkan mampu meningkatkan kesehatan untuk ibu dan anak (12). Seseorang yang tidak memiliki jaminan kesehatan cenderung memiliki akses yang terbatas di pelayanan kesehatan, seperti screening, perawatan, dibandingkan mereka yang terjamin dalam suatu asuransi kesehatan (13,14). Di Indonesia sendiri sebenarnya pelayanan Keluarga Berencana (KB) ditanggung oleh BPJS Kesehatan seperti konseling hingga pemberian obat dan pemasangan alat kontrasepsi. Semua biaya ditanggung oleh BPJS Kesehatan asalkan prosedur sudah sesuai dengan peraturan yang ada dan tentunya dengan indikasi medis (15). Selain itu BPJS Kesehatan juga dapat digunakan pada setiap Pusat Kesehatan Masyarakat (Puskesmas) yang ada di setiap kecamatan. Jadi mengenai akses untuk mendapatkan pelayanan KB secara gratis, masyarakat sudah dapat menjangkaunya dengan mudah.

\section{KESIMPULAN DAN SARAN}

Tren jarak kelahiran pendek pada pengguna kontrasepsi di Indonesia dari tahun $2002-2017$ mengalami peningkatan yaitu 61,07\% (Tahun 2012), 62,63\% (Tahun 2007), 65,27\% (Tahun 2012) dan $68,04 \%$ (Tahun 2017). Dari hasil ini dapat disimpulkan bahwa penggunaan KB belum cukup efektif untuk mencegah terjadinya jarak kelahiran pendek. Jika dilihat dari analisis bivariat yang sudah distratifikasi oleh beberapa variabel, terlihat bahwa variabel asuransi kesehatan dari tahun 2012 
- 2017 mempunyai pengaruh yang cukup penting dalam mencegah terjadinya jarak kelahiran pendek pada pengguna kontrasepsi. Saran dari penelitian ini adalah perlunya penyuluhan atau sosialisasi yang lebih masif mengenai penggunaan dan manfaat dari $\mathrm{KB}$, dikarenakan $\mathrm{KB}$ cukup memegang peranan penting dalam mencegah terjadinya jarak kelahiran pendek pada pengguna $\mathrm{KB}$, meskipun tren jarak kelahiran pendek pada pengguna $\mathrm{KB}$ terus mengalami peningkatan.

\section{Daftar Pustaka}

1. United Nation. South-Eastern Asia Population [Internet]. United Nations; Department of Economic and Social Affairs; Population Division. 2019. Available from: https://www.worldometers.info/wor ld-population/south-eastern-asiapopulation/

2. WHO. Reproductive Health Indicators. Geneva; 2006.

3. Singh R, Tripathi V, Kalaivani M, Singh K, Dwivedi SN.

Determinants of Birth Intervals in Tamil Nadu in India: Developing Cox Hazard Models with Validations and Predictions. Rev Colomb Estadística [Internet]. 2012;(2):289-307. Available from: http://www.scielo.org.co/scielo.php ?script=sci_arttext\&pid=S0120$17512012000200007 \&$ lang=pt

4. WHO. Report of a WHO Technical Consultation on Birth Spacing. 2006; (June). Available from: http://apps.who.int/iris/bitstream/10 665/69855/1/WHO_RHR_07.1_eng .pdf

5. Kemenkes. Situasi dan Analisis Keluarga Berencana. 2014.

6. BKKBN. Strategi Pelaksanaan Program Keluarga Berencana Berbasis Hak untuk Percepatan Akses terhadap Pelayanan Keluarga Berencana dan Kesehatan
Reproduksi yang Terintegrasi dalam Mencapai Tujuan Pembangunan Indonesia. 2015.

7. National Population and Family Planning Board (BKKBN), Statistics Indonesia (BPS), Ministry of Health (Kemenkes) and I. Indonesia 2017 DHS. 2017;

8. Gebrehiwot SW, Abera G, Tesfay K, Tilahun W. Short birth interval and associated factors among women of child bearing age in northern Ethiopia, 2016. BMC Womens Health. 2019;19(1):1-9.

9. White K, Teal SB, Potter JE. Contraception afeter delivery and short IPI in US. 2016;8(5):583-92.

10. Kurniawati D, Prasetyo S. Birth intervals among multiparous women in Indonesia. Kesmas.

2016;10(4):150-5.

11. Begna Z, Assegid S, Kassahun W, Gerbaba M. Determinants of inter birth interval among married women living in rural pastoral communities of southern Ethiopia:

A case control study. BMC

Pregnancy Childbirth [Internet]. 2013;13(1):1. Available from: BMC Pregnancy and Childbirth

12. Lambon-Quayefio M, Owoo NS. Determinants and the impact of the National Health Insurance on neonatal mortality in Ghana. Health Econ Rev. 2017;7(1).

13. Newman K. Socioeconomic disparities in health: Pathways and policies - ProQuest. Health Aff [Internet]. 2002;21(2):60-76. Available from: http://search.proquest.com.libweb.li b.utsa.edu/docview/204621250

14. Fitri A, Adisasmita A, Mahkota R. Pengaruh Jarak Kelahiran terhadap Kematian Bayi di Indonesia, Filipina, dan Kamboja (Analisis Data Survei Demografi Kesehatan). $\mathrm{J}$ Epidemiol Kesehat Indones. 2017;1(2):45-52.

15. BPJS Kesehatan. Ini Strategi 
Kepatuhan dan Pemantapan

Info BPJS Kesehat. 2016;(33):12.

Layanan BPJS Kesehatan 2016. 